\title{
Experimental proof of thiophene hydrodesulfurization reaction steps by isotope $\left({ }^{14} \mathrm{C}\right)$ labeled thiophene
}

\author{
Pál Tétényi ${ }^{1} \cdot$ Tibor Szarvas $^{1} \cdot$ Tamás Ollár $^{1}$ [D
}

Received: 18 August 2021 / Accepted: 12 October 2021 / Published online: 22 October 2021

(c) The Author(s) 2021

\begin{abstract}
Hydrodesulfurization of thiophene has been studied over alumina supported sulfided molybdena, nickel-promoted molybdena and over nickel (Mo, NiMo and Ni) catalysts. The experiments were carried out with a mixture of thiophene, labeled with radioactive carbon (thiophene-[G-]- ${ }^{14} \mathrm{C}$ ) and of non-radioactive tetrahydrothiophene (1:1 mol ratio) in a micro catalytic system. It was established, that the main products were tetrahydrothiophene- ${ }^{14} \mathrm{C}$, 1-butene- ${ }^{14} \mathrm{C}$, 2-butene- $-{ }^{14} \mathrm{C}$, butane- ${ }^{14} \mathrm{C}$. Tetrahydrothiophene- ${ }^{14} \mathrm{C}$ was a major intermediate in the conversion of thiophene $-{ }^{14} \mathrm{C}$ in the experimental condition applied. The amounts of converted tetrahydrothiophene on the catalysts were substantially higher than those of thiophene under the same conditions. Hydrothiophene and dihydrothiophene $-{ }^{14} \mathrm{C}$ were intermediate products in the hydrodesulfurization of thiophene and tetrahydrothiophene. The hydrodesulphurization of tetrahydrothiophene was paired with dehydrogenation, producing small amounts of thiophene. The experimental results have been considered in the discussion of the mechanism of thiophene and tetrahydrothiophene desulfurization reaction pathway.
\end{abstract}

Keywords Mo · NiMo · Thiophene HDS · HDS mechanism · Isotope labeled thiophene

\section{Introduction}

The removal of sulfur is crucially important in processing of petroleum feed materials. It is accomplished via hydrodesulfurization (HDS) of the sulfur containing organic compounds. Generally, thiophene (TH) is used as a model reactant to study this process, because it represents the sulfur containing aromatic compounds, that are, in some extent, resistant to desulfurization.

Tamás Ollár

ollar.tamas@ek-cer.hu

1 Institute for Energy Security and Environmental Safety, Centre for Energy Research,

Konkoly-Thege M. 29-33, 1121 Budapest, Hungary 
There have been numerous concepts published about the mechanism of HDS of $\mathrm{TH}$ [1-16] in the literature. As a matter of fact, one of them [2] states that the rupture of the $>\mathrm{HC}-\mathrm{S}-$ bond is the consequence of the $\beta-\mathrm{C}-\mathrm{H}$ dissociation and the hydrogenation of the fragment with other hydrogen molecules. Another concept is based on the direct dissociation of the $>\mathrm{C}-\mathrm{S}$ bond due to the interaction with outside hydrogen, followed by hydrogenation of the fragments and desorption of the hydrogenated products from the catalysts surface [3]. It has also been proposed [5] that the partial hydrogenation of the $>\mathrm{C}=\mathrm{C}<$ bonds in $\mathrm{TH}$ results in the formation of tetrahydrothiophene (THT), an intermediate of the hydrocarbons produced in HDS of thiophene.

This statement has been confirmed by other study [6], where the conversion rate of thiophene was compared to that of the THT during HDS. The HDS turnover frequencies of $\mathrm{TH}$ and THT were compared on catalysts containing $\mathrm{Mo}^{\mathrm{n}+}$-ions in different oxidation states $(n=2,4$ or 6$)$. The HDS activity was substantially higher on samples with $\mathrm{Mo}^{2+}$, than on with $\mathrm{Mo}^{4+}$ and the activity was the minimal on the samples containing $\mathrm{Mo}^{6+}$. The activity on the silica supported sulfided molybdenum $\left(\mathrm{MoS}_{2}\right)$ samples showed much higher catalytic activity, than those on the nonsulfided ones.

A simplified model of the HDS of TH (Fig. 1) presents the latter two of the above mentioned mechanisms [5, 6], indicating both the direct and stepwise HDS reactions. Moses et al. [17] compared the two pathways with DFT calculations and presented a detailed overview of the reactions. Not only the presence of both routes of HDS, but also the different role of Mo- and S-sites in HDS on the sulfided catalysts was explained.

The HDS of TH has also been studied by using deuterium isotope on sulfided, alumina supported $\mathrm{Mo}, \mathrm{Ni}$ and $\mathrm{Ni}$ - promoted Mo catalyst [18]. The interaction of TH with $\mathrm{D}_{2}$ and with deuterium containing $\mathrm{H}_{2}$ indicated that the HDS proceeds via the interaction of the $\mathrm{TH}$ with external hydrogen and that intermolecular $\mathrm{TH}$ conversion with participation of their $\beta$-hydrogen atom does not play role in the reaction.

Apart from the detailed studies of sulfur uptake and exchange in a number of laboratories with ${ }^{35} \mathrm{~S}$ [19], radiotracer studies on the mechanism of this reaction with ${ }^{14} \mathrm{C}$ labeled sulfur containing compounds have not been carried out [20]. However, the conversion of ${ }^{14} \mathrm{C}$ labeled thiophene was studied by Somorjai and Bussel [21]. They focused on the formation of carbon on the clean and on carbide

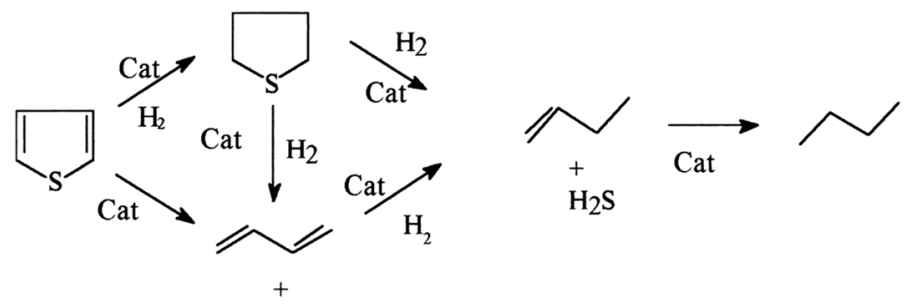

$\mathrm{H}_{2} \mathrm{~S}$

Fig. 1 The simplified possible ways for HDS of thiophene [5] 
containing single crystal Mo(100) catalyst, they observed increased HDS activity of the sulfided samples when the sulfur was removed from the surface by evacuation. Our results $[22,23]$ confirmed their observation: we observed linear correlation between the sulfur exchange capacity and the HDS activity of sulfided, nonpromoted and of Ni-, Co-, $\mathrm{Pd}$ - and Pt promoted molybdena-alumina, furthermore of $\mathrm{Ni}$ - promoted silica-alumina supported tungsten catalysts. The existence of this correlation indicates that the sulfur exchange capacity is similar to the HDS activity of the sulfided catalysts. However, it had been shown in several publications [24, 25], sulfur exchange is not equal to sulfur replacement in the course of thiophene HDS. The correlation observed by the authors relates to sulfur replacement and catalytic activity and is correct only for the catalysts of similar composition. Similar catalysts (NiMo, NiW on $\mathrm{Al}_{2} \mathrm{O}_{3}$ ) were compared in our last study, and the linear correlation between sulfur exchange and catalytic activity was even clearer than in our previous work [26]. Comparison of catalysts differ by carrier nature, active metals etc., may not lead to linear correlation but to more complicated dependence.

We provided a study of the selectivity in TH conversion on three catalysts of substantially different HDS activities observed in our former [27, 28] studies of sulfided Mo-alumina and NiMo-alumina of 0.35 atomic Ni/Mo ratio (Mo and NiMo) and of the alumina supported nickel catalyst $(\mathrm{Ni})$. In the investigation the conversion of a mixture of TH with THT has been studied, whereas the TH was labeled with radioactive carbon (thiophene- $-{ }^{14} \mathrm{C}$ ). In additional experiments, it has been established [16] that THT is not an intermediate at atmospheric pressure but it may be a major intermediate at high pressure and low temperature $[8,9]$. Therefore, it was particularly interesting to study the formation of THT and 2,5-dihydrothiophene in conditions of thiophene HDS at atmospheric pressure, different temperature using markedly different catalysts.

There has been used ${ }^{14} \mathrm{C}$ radioisotope in the present study for the answer to these questions and the experiments have been carried out at atmospheric pressure and different temperature in the micro catalytic pulse system applied in our laboratory described in details elsewhere [27-29]. Our detailed comments are given on the nature of the conversion products and the elementary steps of the mechanism of thiophene HDS.

\section{Experimental}

The experiments have been performed on sulfided Mo, NiMo, and Ni samples in conditions, applied before. $\mathrm{MoO}_{3} / \mathrm{Al}_{2} \mathrm{O}_{3}$ of 12 mass $\%$ of (Mo) samples were prepared by impregnation of a Pural- $\mathrm{Al}_{2} \mathrm{O}_{3}\left(210 \mathrm{~m}^{2} / \mathrm{g}\right)$ with an aqueous solution of ammonium heptamolybdate. The $\mathrm{Ni} / \mathrm{Al}_{2} \mathrm{O}_{3}$ catalyst $(\mathrm{Ni})$ was prepared by impregnation of the alumina, with an aqueous solution of nickel nitrate calculated for $\sim 6$ mass\% of $\mathrm{NiO}$ on the catalyst. The wet samples were dried and calcined for $5 \mathrm{~h}$ at $723 \mathrm{~K}$. The Ni-promoted molybdena-alumina catalyst $(1.75$ mass $\%$ calculated for $\mathrm{Ni}$ ) were prepared by impregnation of the dried, (not calcined) Mo sample with aqueous nickel nitrate solution, dried and calcined for $5 \mathrm{~h}$ at $773 \mathrm{~K}$ temperature. The catalysts samples have been sulfided with a mixture of hydrogen sulfide $\left(\mathrm{H}_{2} \mathrm{~S}\right)$ 
with hydrogen $\left(\mathrm{H}_{2}\right)$ of 1:1 molar ratio. Table 1 presents the data of the catalysts specific surface area determined by $\mathrm{N}_{2}$ adsorption and their chemical content, calculated from the amounts and correlation of materials applied for preparation [31] and determined [28] by prompt gamma activation analysis (PGAA). There are also presented in Ref. [31] the method of treatment of the samples with mixtures $\mathrm{H}_{2} \mathrm{~S} / \mathrm{H}_{2}$ and detailed data of the irreversible sulfur uptakes determined by their sulfidation in circulation system [22] with $\mathrm{H}_{2} \mathrm{~S}$, containing radioactive sulfur $\left(\mathrm{H}_{2}{ }^{25} \mathrm{~S}\right)$. The amount of sulfur uptakes of catalysts were determined from the decrease of the gas phase radioactivity values $\left({ }^{\mathrm{G}} \mathrm{S}_{\mathrm{irr}}\right.$ ) at circulating of the mixtures $\mathrm{H}_{2}{ }^{35} \mathrm{~S}+\mathrm{H}_{2}$ up to the constant gas phase radioactivity values were reached. The amount of irreversible sulfur on the catalysts $\left({ }^{\mathrm{S}} \mathrm{S}_{\mathrm{irr}}\right)$ were determined by the radioactivity of the samples after their treatment in vacuum [31], and calculated also $\left({ }^{\mathrm{G}} \mathrm{S}_{\text {irr }}\right)$, from the amounts of sulfur uptake values by vacuum treated samples determined in their repeated sulfur uptake experiments provided with $\mathrm{H}_{2}{ }^{25} \mathrm{~S} / \mathrm{H}_{2}$ presented also in Ref. [31].

The chemicals applied in the experiments were the follows: thiophene and tetrahydrothiophene Merck Co of purity $>98 \%$ and $~ 99.9$, and hydrogen Messer Hungarogas I.T. of purity $99.5 \%$.

Thiophene- $-{ }^{14} \mathrm{C}$ was synthesized according to the following procedure: $1.378 \mathrm{~g}$ $\mathrm{BaCO}_{3}$ and $1.9 \mathrm{mg} \mathrm{Ba}{ }^{14} \mathrm{CO}_{3}$ (of $10.73 \mathrm{GBq} / \mathrm{g}$ specific radioactivity) were mixed with barium metal by filling them in a Pyrex tube, and the mixture was heated at $973 \mathrm{~K}$ in argon flow, and reduced rapidly to barium carbide $-{ }^{14} \mathrm{C}$ at this temperature. The Pyrex tube was broken then to pieces and the barium carbide $-{ }^{14} \mathrm{C}$ hydrolyzed by a solution of hydrochloric acid in hydrogen flow in a suitable apparatus. The formed acetylene- $-{ }^{14} \mathrm{C}$ was purified on pellets of magnesium perchlorate and sodium hydroxide, frozen with liquid nitrogen in a trap and it was connected to a vacuum manifold. The hydrogen was removed, and the amount of expanded acetylene $-{ }^{14} \mathrm{C}$ was determined by pressure of that. It was mixed with the amount of hydrogen sulfide required by the stoichiometry for the production of thiophene. The mixture was homogenized and reacted on $\mathrm{Al}_{2} \mathrm{O}_{3}$ at $623 \mathrm{~K}$ in a circulation process. The formation of thiophene $-{ }^{14} \mathrm{C}$ was followed by $\mathrm{GC}$ analysis, then the gas mixture was frozen in liquid nitrogen. After the exchange of cooling to $-40{ }^{\circ} \mathrm{C}$ the

Table 1 Characteristic data of the catalyts

\begin{tabular}{|c|c|c|c|c|c|c|c|}
\hline \multirow[t]{2}{*}{$\begin{array}{l}\text { Catalyst sup- } \\
\text { ported with } \mathrm{Al}_{2} \mathrm{O}_{3}\end{array}$} & \multicolumn{2}{|c|}{$\mathrm{Ni}^{\mathrm{a}} 10^{17}$ atoms $/ \mathrm{mg}$} & \multicolumn{2}{|c|}{$\mathrm{Mo}^{\mathrm{a}} 10^{17}$ atoms $/ \mathrm{mg}$} & \multirow{2}{*}{$\begin{array}{l}\text { Surface } \\
\text { area }^{b} \mathrm{~m}^{2} / \mathrm{g} \\
\text { BET }\end{array}$} & \multicolumn{2}{|c|}{$\begin{array}{l}\text { Sulfur } \\
10^{17} \text { atoms } / \mathrm{mg}\end{array}$} \\
\hline & Calculated & PGAA & Calculated & PGAA & & ${ }^{\mathrm{S}_{\mathrm{irr}}}$ & ${ }^{\mathrm{G}} \mathrm{S}_{\mathrm{irr}}$ \\
\hline Mo & - & - & 5.03 & 6.7 & 155 & 5.8 & 7.0 \\
\hline NiMo & 1.80 & 2.25 & 5.03 & 6.4 & 179 & 10.5 & 10.4 \\
\hline $\mathrm{Ni}$ & 6.15 & 6.40 & - & - & 164 & 4.5 & 4.5 \\
\hline
\end{tabular}

${ }^{a}$ The content of Ni and Mo atoms in the samples, as calculated and as they determined [25] by prompt gamma activation analysis(PGAA)

${ }^{\mathrm{b}}$ The specific surface areas of the samples before sulfidation, determined by adsorption of $\mathrm{N}_{2}$

${ }^{\mathrm{c}}$ The amounts of sulfur, irreversibly bonded $\left({ }^{\mathrm{S}} \mathrm{S}_{\text {irr }}\right.$ calculated from catalysts radioactivity and ${ }^{\mathrm{G}} \mathrm{S}_{\mathrm{irr}}$ calculated from changes of gas phase radioactivity values at sulfidation of the samples with $\mathrm{H}_{2}{ }^{35} \mathrm{~S}$ ) [28] 
non-reacted acetylene- ${ }^{14} \mathrm{C}$ and hydrogen sulfide were separated by freezing in a reservoir. Stopping of the freezing, the formed thiophene- ${ }^{14} \mathrm{C}$ was distilled and diluted with non-radioactive thiophene. The chemical purity (99\%) and the specific radioactivity $(180,750 \pm 425 \mathrm{dpm} / \mathrm{mg})$ of the product was determined by GC and LSC, respectively.

The catalytic conversion of non-labeled THT and of its mixtures with thiophene${ }^{14} \mathrm{C}$ was carried out on sulfided catalyst samples of $10 \mu \mathrm{l}$ in the pulse catalytic micro system applied in our laboratory described in details elsewhere [29, 30]. The amount of THT and TH conversion products were determined by GC. In experiments with thiophene- ${ }^{14} \mathrm{C}$ the fractions were introduced into three different vessels absorbing (i) $\mathrm{C}_{4}$ products, (ii) the non-converted thiophene ${ }^{14} \mathrm{C}$, and (iii) the THT burned by FID, absorbed in solution of $0.1 \mathrm{M}$ sodium-hydroxide. The radioactivity values of these fractions was determined in LSC using Clinisosol liquid scintillation cocktail and calculated the distribution of the radioactivity (\%) among the fractions.

The degrees of conversion was calculated from the values of non-reacted THT and TH at injecting pulses of liquids (of $4.3 \mu$ l, i.e. $1.71 \times 10^{18}$ and $1.179 \times 10^{18} \mathrm{~mol}-$ ecules of THT and TH). The flow rate of the carrier gas (30 or $40 \mathrm{NTP} \mathrm{ml} / \mathrm{min}$ of $\mathrm{H}_{2}$ ) was accepted as equivalent with the low rate of the reactant pulses [32, 33]. The experiments of the reactants conversions have been provided at the temperature range of 593-673 K. The obtained data in the majority of cases indicated definite increase of the conversion rate of THT and $\mathrm{TH}$ at increasing temperature. The degree of the THT conversion on the samples, containing NiMo and Ni was very high-near to a total one-at temperatures over $593 \mathrm{~K}$.

On these two catalyst samples the temperature dependence of the THT conversion was determined at a wider-473-673 K-interval of the temperature, and the values of the temperature coefficients-accepted generally, for virtual activation energy values - of the HDS of these compounds were calculated from the conversion data determined at a lower-473-573 K-interval.

\section{Results and discussion}

Table 1 presents the characteristic data of the catalyst, used in the experiments. The HDS conversion of the mixtures of thiophene, labeled with radioactive carbon thiophene- ${ }^{14} \mathrm{C}$ and not labeled THT (of 1:1 ratio) have been studied in the temperature interval of 593-673 K. Fig. 2 shows the results of chromatographic separation and analysis of the conversion products. Conversion data determined during the HDS of these mixtures can be found in Fig. 3. The results indicating the appearance of THT${ }^{14} \mathrm{C}$, besides the $\mathrm{C}_{4}$-hydrocarbon- ${ }^{14} \mathrm{C}$ products, minimal amount of 2,5 -DHT ${ }^{14} \mathrm{C}$ and 2-HTH- ${ }^{14} \mathrm{C}$. Furthermore, data in these tables indicate substantial radioactivity values of THT, consequently that is a main intermediate of HDS of thiophene- ${ }^{14} \mathrm{C}$ at atmospheric pressure. This is different from the observation of Borgna et al. [16] and is connected presumably with the differences in the reaction conditions applied herein.

By comparing the data in Fig. 3, it can be seen that the highest radioactivity in the THT obtained on the sulfided Mo catalyst at the flow rate of $30 \mathrm{NTP} \mathrm{ml} / \mathrm{min}$ at 


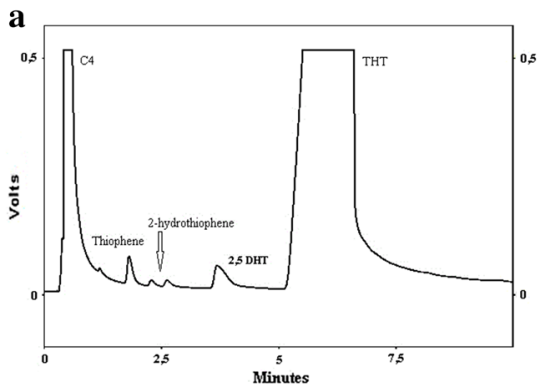

b

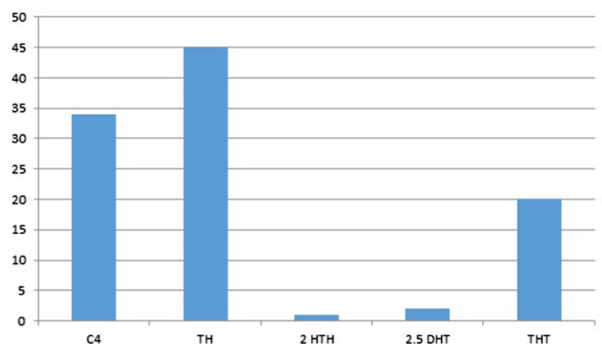

Fig. 2 Distribution of the products of HDS conversion of the mixtures of thiophene, labeled with radioactive carbon thiophene- ${ }^{14} \mathrm{C}$ and not labeled THT (of 1:1 ratio) in pulse reactor over $\mathrm{MoS}_{2}$ catalyst at $623 \mathrm{~K}$. The results of chromatographic separation and analysis of the conversion products (a) and the distribution of the radioactivity among the conversion productsproducts (b) (Products: $\mathrm{C}_{4}, \mathrm{TH}$ thiophene, 2 HT 2-hydrothiophene, 2,5 DHT 2,5 dihydrothiophene, THT tetrahydrothiophene)

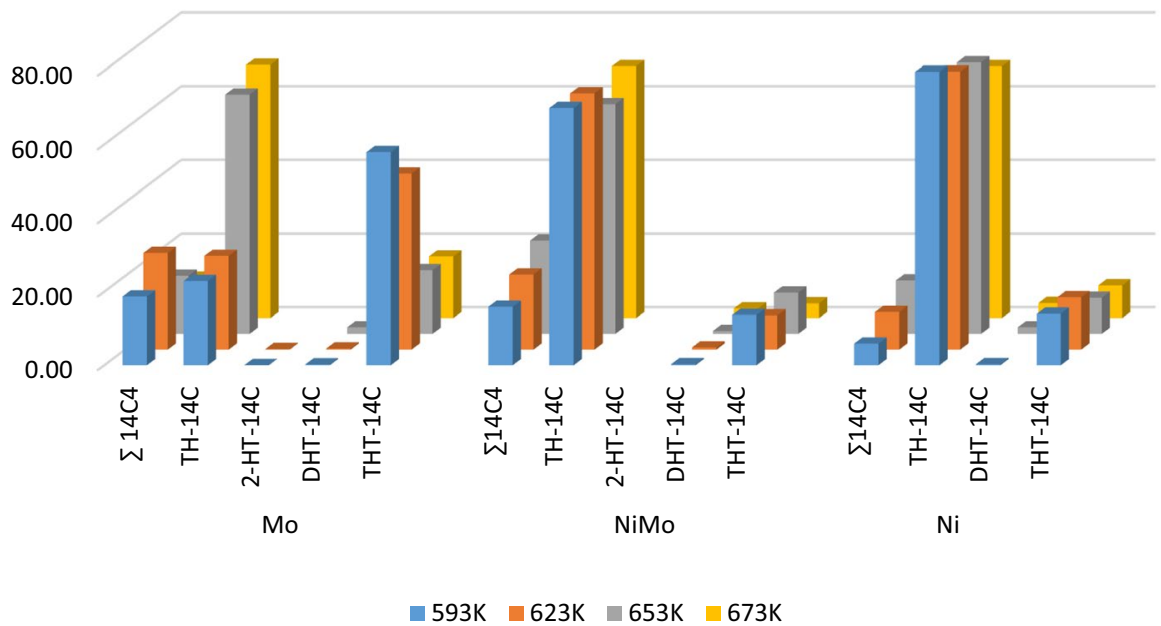

Fig. 3 Distribution of the radioactivity values (\%) among the products at the conversion of the mixture of thiophene- ${ }^{14} \mathrm{C}+$ tetrahydrothiophene (molar ratio $1: 1$ ) on sulfided catalysts of $10 \mathrm{mg}$ at different temperature and $30 \mathrm{NTP} \mathrm{ml} / \mathrm{min}$ flow rate of $\mathrm{H}_{2}(\mathrm{TH}$ :thiophene,DHT: dihydrothiophene, THT:tetrahydrothiophene)

the conversion of the mixtures (thiophene- ${ }^{14} \mathrm{C}+$ tetrahydrothiohene). The radioactivity of THT was lower on Ni, and a minimal value was measured on the NiMo catalyst. This is connected with the increase of ${ }^{14} \mathrm{C}$ infiltration at increasing temperature and with the substantially higher amounts of the $\mathrm{C}_{4}$ hydrocarbons, produced from THT on NiMo.

In all other cases the radioactivity values of $\mathrm{TH}-{ }^{14} \mathrm{C}$ were substantially $3-6$ times higher than those of THT- ${ }^{14} \mathrm{C}$. This is the consequence of the much higher extent of HDS and higher degrees of THT conversion, than those of TH, as this was indicated by comparison of the respective data in Fig. 3 with those in Tables 4. Minimal 


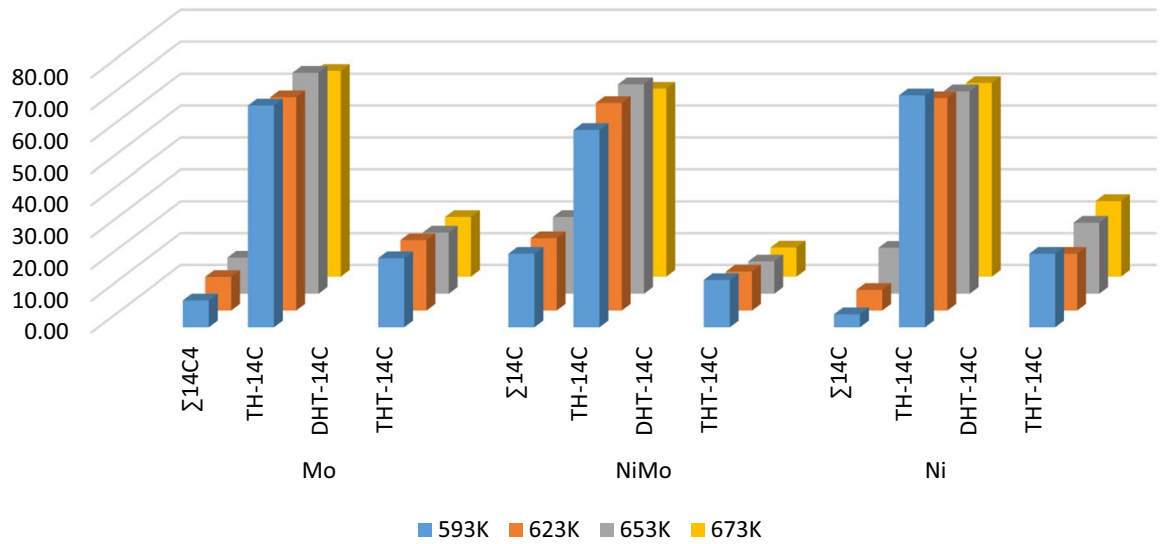

Fig. 4 Distribution the radioactivity values (\%) among the products at the conversion of the mixture of $\mathrm{TH}-{ }^{14} \mathrm{C}+\mathrm{THT}$ (molar ratio $1: 1$ ) on sulfided catalysts of $10 \mathrm{mg}$ at different temperature and $40 \mathrm{NTP} \mathrm{ml} /$ min flow rate of $\mathrm{H}_{2}$

Table 2 Percentage of hydrocarbon products at the HDS of thiophene at $673^{\circ} \mathrm{K}$ and $30 \mathrm{NTP} \mathrm{ml} / \mathrm{min}$ flow of $\mathrm{H}_{2}$

\begin{tabular}{lccll}
\hline Catalyst & Butane & 1-Butene & 2-Butene & 2-Bu/1.Bu \\
\hline Mo & 8.4 & 29.7 & 55.9 & 1.88 \\
NiMo & 3.3 & 29.6 & 65.1 & 2.20 \\
Ni & 29.4 & 8.8 & 47.7 & 5.42 \\
\hline
\end{tabular}

Reaction time $5 \mathrm{~min}$ in circulation system

amounts of DHT also formed at the flow rates of $30 \mathrm{NTP} \mathrm{ml} / \mathrm{min}$, as that is indicated on tables.

The ratio of the HDS conversion were lower at higher-40 NTP $\mathrm{ml} / \mathrm{min}$ - flow rates of the mixtures of $\mathrm{TH}-{ }^{14} \mathrm{C}+\mathrm{THT}$ (Fig. 4). The absence of radioactive DHT at the conversion at these flow rates, different from the case of THT- $-{ }^{14} \mathrm{C}$, indicated the stepwise HDS of TH. The absence of DTH among the products is connected presumably by substantially higher amounts of the converted THT in comparison with those of TH.

The data of repeated extents and rates $\left(\mathrm{m}_{\mathrm{TH}}\right)$ of the conversion of $\mathrm{TH}$ is presented in Table 4, at $673 \mathrm{~K}$ on the three catalysts. Measurements by GC indicate the highest ratio of the $\mathrm{C}_{1}-\mathrm{C}_{2}$ - butenes and butane among them, in agreement with our former observation Table 2. Similar data have been found in the distribution of the radioactivity in $\mathrm{C}_{4}$ (Table 3.) The amount of 2-butene is higher than 1-butene + butane among the $\mathrm{C}_{4}$ products of thiophene conversion wich indicates the hydrogenation of thiophene producing 2-hydrothiophene followed by additional hydrogenation the isomerization of $>\mathrm{C}=\mathrm{C}<$ resulting the formation of 2,5DHT. There have been observed also minimal amounts of DHT and THT at the conversion. This observation raised the question of stepwise HDS of TH.

This question initiated to perform experiments of the separate conversion of THT on the same catalysts. The determined data are presented in Figs. 5, 6. Comparison 
Table 3 Distribution of the radioactivity (\%) in $\mathrm{C}_{4}$ products at $673 \mathrm{~K}$, and $30 \mathrm{NTP} \mathrm{ml} / \mathrm{min}$ flow of $\mathrm{H}_{2}$

\begin{tabular}{lllll}
\hline Catalyst & Butane & 1-Butene & 2-Butene & 2-Bu/1-Bu \\
\hline Mo & 8.9 & 31.6 & 59.4 & 1.88 \\
NiMo & 3,4 & 29.9 & 66.6 & 2.20 \\
Ni & 34.2 & 10.2 & 55.5 & 5.50 \\
\hline
\end{tabular}

Reaction time $5 \mathrm{~min}$ in circulation system

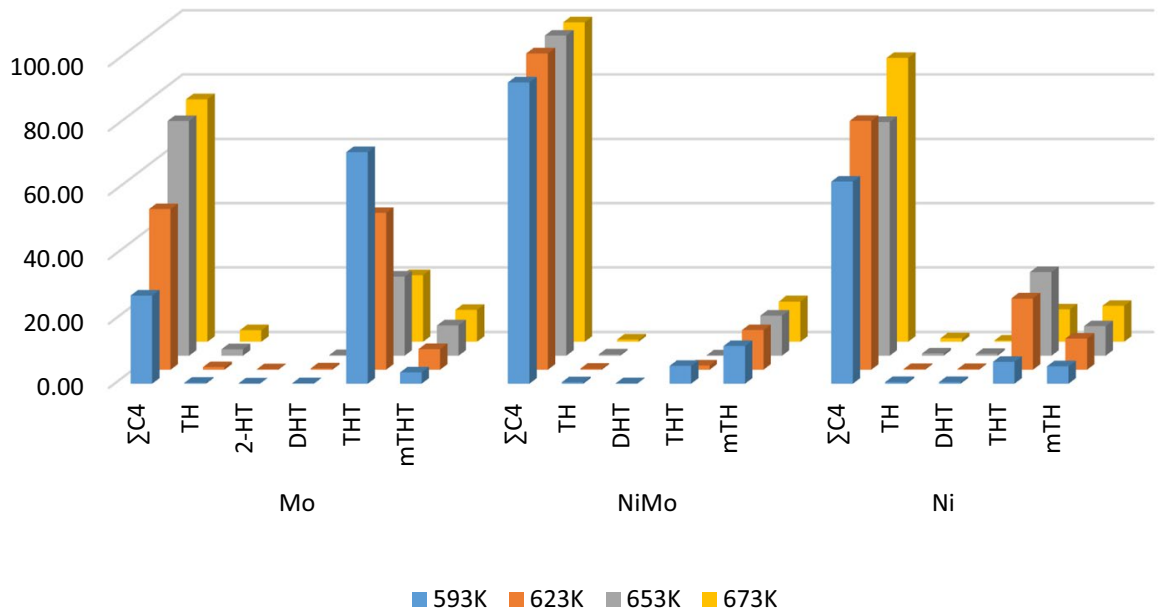

Fig. 5 Conversion of THT on sulfided Mo, NiMo and Ni catalysts catalyst. Dynamic system; amount of catalysts: $10 \mathrm{mg}$; Flow rate of $\mathrm{H}_{2}\left(\mathrm{v}_{1}\right): 30 \mathrm{NTP} \mathrm{ml} / \mathrm{min}$, i.e. $1.25 \times 10^{18} \mathrm{~mol} / \mathrm{s} \mathrm{mg}_{\text {cat }}$; in $\%$ of components containing four $\mathrm{c}$ atoms; $\mathrm{m}_{\mathrm{THT}}$ : tetradydrothiophene conversion rates in units of $10^{17} \mathrm{~mol} / \mathrm{s} \mathrm{mg}_{\text {cat }}$

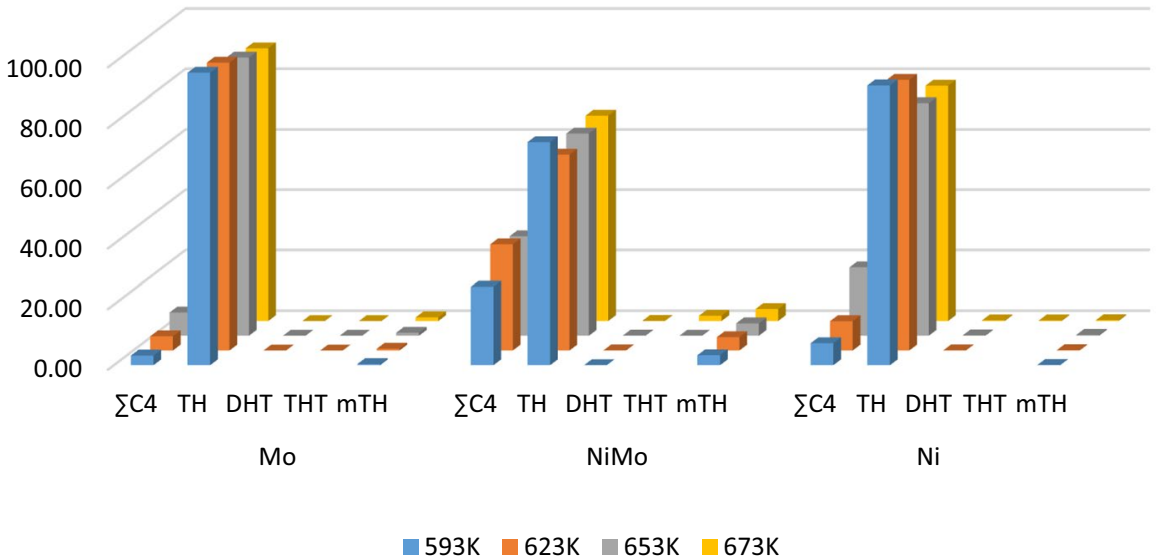

Fig. 6 Conversion of TH on sulfided Mo,NiMo and Ni catalysts. Dinamic system; amount of catalysts: $10 \mathrm{mg}$; Flow rate of $\mathrm{H}_{2}\left(\mathrm{v}_{1}\right): 30 \mathrm{NTP} \mathrm{ml} / \mathrm{min}$, i.e. $1.25 \times 10^{18} \mathrm{~mol} / \mathrm{s} \mathrm{mg}$ cat ; in percents of components, containing four carbon atoms; $\mathrm{m}_{\mathrm{TH}}$ : thiophene conversion rates in units of $10^{17} \mathrm{~mol} / \mathrm{s} \mathrm{mg}_{\text {cat }}$ 
Table 4 Conversion rates of $\mathrm{TH}$ on sulfided Mo, NiMo, and $\mathrm{Ni}$ catalysts in temperature interval of $593-673 \mathrm{~K}$

\begin{tabular}{|c|c|c|c|c|c|}
\hline \multirow[t]{2}{*}{$\mathrm{T}^{\circ} \mathrm{K}$} & \multicolumn{2}{|c|}{ Conversion } & \multicolumn{3}{|c|}{ Product selectivity } \\
\hline & $\%$ & $\mathrm{~m}_{\mathrm{TH}}$ & $\sum \mathrm{C}_{4}$ & DHT & THT \\
\hline \multicolumn{6}{|l|}{ Mo } \\
\hline 593 & 28.0 & 3.50 & 0.98 & $>0.01$ & 0.01 \\
\hline 623 & 51.3 & 6.41 & 0.98 & $>0.01$ & $>0.02$ \\
\hline 653 & 75.5 & 9.44 & 0.97 & $>0.005$ & $>0.03$ \\
\hline 673 & 79.4 & 9.93 & 0.95 & $>0.005$ & $>0.04$ \\
\hline 593 & 24.9 & 3.11 & 0.98 & $>0.01$ & 0.01 \\
\hline \multicolumn{6}{|l|}{ NiMo } \\
\hline 593 & 26.2 & 3.3 & 0.99 & $>0.01$ & 0 \\
\hline 623 & 35.2 & 4.4 & $\sim 1.0$ & $>0.01$ & 0 \\
\hline 653 & 33.1 & 4.1 & 0.99 & $>0.01$ & $>0.01$ \\
\hline 673 & 32.0 & 4.0 & 0.99 & $>0.01$ & $>0.01$ \\
\hline 593 & 23.4 & 2.9 & 0.99 & $>0.01$ & 0 \\
\hline \multicolumn{6}{|l|}{$\mathrm{Ni}$} \\
\hline 593 & 7.5 & 0.09 & 0.97 & 0 & 0 \\
\hline 623 & 10.9 & 0.13 & 0.99 & $>0.01$ & 0 \\
\hline 653 & 23.0 & 0.29 & 0.98 & 0 & 0 \\
\hline 673 & 22.2 & 0.28 & 0.95 & $0.01>0.01$ & \\
\hline 593 & 5.7 & 0.07 & 0.98 & 0 & 0 \\
\hline
\end{tabular}

Dynamic system; amount of catalysts: $10 \mathrm{mg}$; $\mathrm{v}_{1}$ : $30 \mathrm{NTP} \mathrm{ml} / \mathrm{min}$, i.e. $1.25 \times 10^{18} \mathrm{~mol} / \mathrm{s} \mathrm{mg} ; \mathrm{m}_{\mathrm{TH}}$ : TH conversion rate at $623 \mathrm{~K}$ in units $10^{17} \mathrm{~mol} / \mathrm{s} \mathrm{mg}_{\text {cat }}$

of these data with those in Table 4 indicates substantially higher extents of the THT conversion in comparison with those of $\mathrm{TH}$ in the same temperature intervals. Total conversion was obtained on the NiMo in the same (593-673 K) temperature range and near total conversion (70-80\%) on the $\mathrm{Ni}$, whereas it was substantially lower on the Mo sample. The small temperature dependent amounts of TH among the products on the three catalysts indicated a minimal dehydrogenation of THT.

The calculated temperature coefficients (visual activation energy values) from the "Arrhenius straight" of the TH conversion were definitely higher on Ni than on Mo in agreement with the higher degree of the TH conversion on Mo, as that is seen on Fig. 7. Different from that, no temperature dependence of the $\mathrm{TH}$ conversion was observed on the NiMo, and the degree of $\mathrm{TH}$ conversion were the highest on this catalyst.

The same temperature dependence of the THT conversion has been also observed on the Mo sample. The conversion rates were substantially higher on the NiMo and $\mathrm{Ni}$, their temperature dependences have been determined from the temperature coefficients at lower-493-553 $\mathrm{K}$-temperature region. The plots of $\log \mathrm{m}$ vs. 1/T calculated from the "Arrhenius straights" of THT conversion are presented on Fig. 8.

Comparison of the data in Figs. 5, 6 with the respective ones in Table 4 indicates substantially higher degrees of the THT conversion in comparison with those values at the conversion of $\mathrm{TH}$. The temperature coefficients of the THT conversion rates 


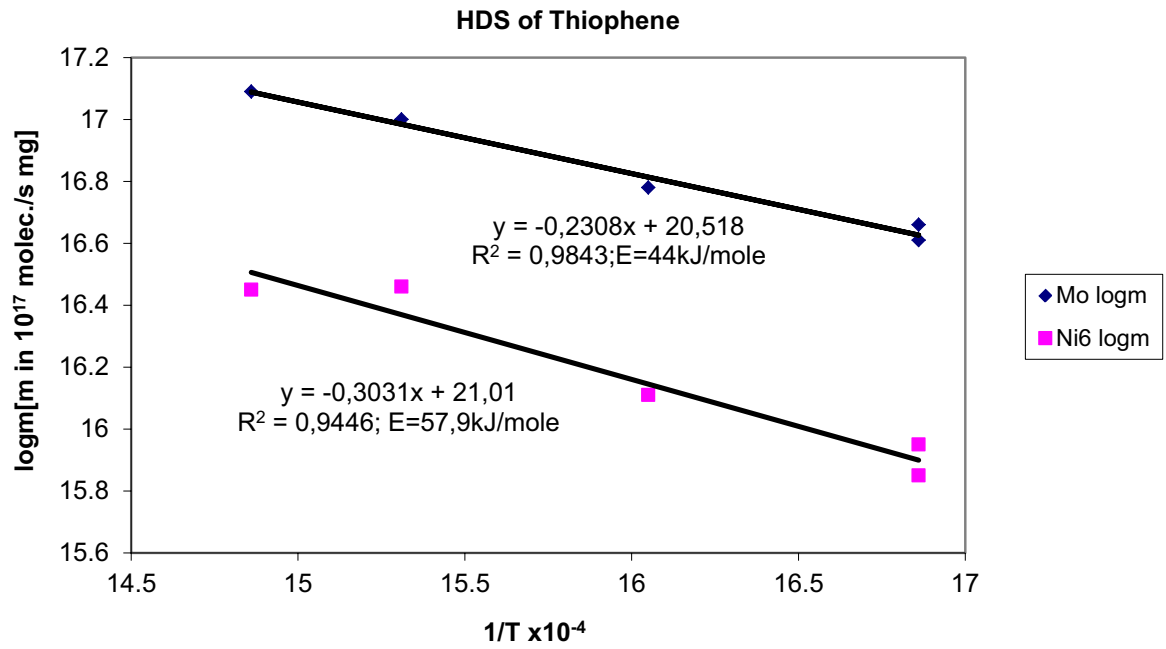

Fig. 7 The calculated temperature coefficients (visual activation energy values) from the "Arrhenius straight" of the thiophene conversion on $\mathrm{Ni}$ and on Mo

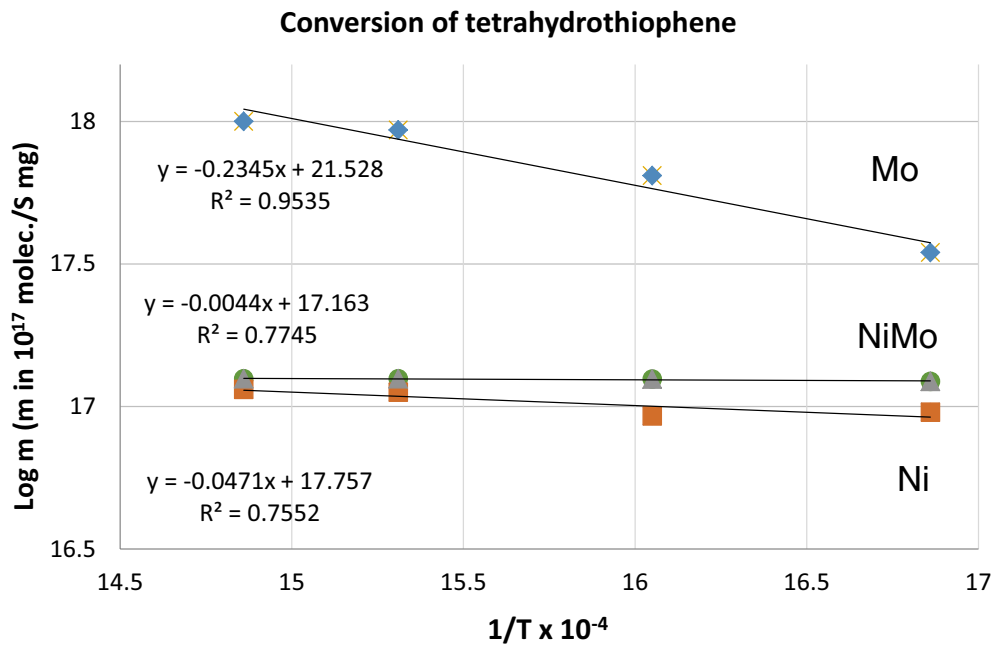

Fig. 8 Conversion of tetrahydrothiophene on sulfided $\mathrm{Ni} / \mathrm{Al}_{2} \mathrm{O}_{3}, \mathrm{Mo} / \mathrm{Al}_{2} \mathrm{O}_{3}$ and $\mathrm{NiMo} / \mathrm{Al}_{2} \mathrm{O}_{3}$ catalysts

were lower on the Mo and NiMo, than that of determined from the TH conversion rates on the same catalysts. Different from this, the temperature coefficient of the THT conversion on the Ni was substantially higher than that of TH.

This observations raise the question: why the amounts and the rates of THT HDS are substantially higher, in comparison with those values of $\mathrm{TH}$ in all respective cases? Our opinion, it is caused by the differences in the bond energy values of the $>\mathrm{C}-\mathrm{S}$ bonds $\left(\mathrm{Q}_{\mathrm{CS}}\right)$, as those are higher in $\mathrm{CH}_{2}=\mathrm{CH}-\mathrm{SH} 318 \mathrm{~kJ}$ (given as 
$76.6 \mathrm{kcal}$ in Ref. [33], than in $\mathrm{CH}_{3} \mathrm{CH}_{2}-\mathrm{SH} 286 \mathrm{~kJ}$ (given as $69 \mathrm{kcal}$ [31]. It follows from the respective bond strengths of $\mathrm{C}_{3} \mathrm{H}_{7} \mathrm{CH}_{2}-\mathrm{SH} \mathrm{Q} \mathrm{CS}_{2}=304.3 \mathrm{~kJ}$ (given as $72.8 \mathrm{kcal}$ [34]), higher than the value of $\mathrm{Q}_{\mathrm{CS}}=251.6 \mathrm{~kJ}$ (given as $60.2 \mathrm{kcal}$ [35]) in $\mathrm{CH}_{2}=\mathrm{CHCH}_{2}-\mathrm{SH}$, that the HDS of 2,5 DHT is higher than that of TH. This approach gives an explanation also for the presence of minimal amounts of 2,5 DHT and 2-HTH among the products of thiophene HDS. The temperature coefficient of the conversion of THT on NiMo is lower substantially, than that on $\mathrm{Ni}$ (Fig. 8). This is caused by the substantially ( three times) higher ratio of the $>\mathrm{C}-\mathrm{C}<$ bond rupture on $\mathrm{Ni}$ in comparison of that at the $\mathrm{TH}$ conversion on this NiMo as the determined before [28].

Fig. 9 represents a schematic diagram over the HDS of TH on the sulfided Mo, NiMo, and Ni catalysts. As can be seen in Fig. 2 could be identified in the prehydrogenation step the formation of $2-\mathrm{HTH}_{-}{ }^{14} \mathrm{C}$ and 2,5 -DHT- ${ }^{14} \mathrm{C}$ in the conversion process of $\mathrm{TH}-{ }^{14} \mathrm{C}$. It was only possible by the application of pulse microanalytical technique since 2-HTH but also 2,2-DHT have a very short life time before the transformation into THT. The main process was the formation of THT in our dynamic system and over the applied catalysts and followed a rapid scission of both $\mathrm{S}-\mathrm{C}$ bond because the both bonds are equivalent and they have lower energy values than $\mathrm{CH}=\mathrm{CH}-\mathrm{SH}$. Our results suggest that butadiene does not form from 2,5-DHT by the elimination of both $\mathrm{S}-\mathrm{C}$ bond. NiMo catalyst had higher effect on this process.

In the conversion of THT minimal amount of 2,5,-DHT 2-HTH and TH could be also identified (Fig. 7) as a consequence of the minor dehydrogenation process on the catalysts.

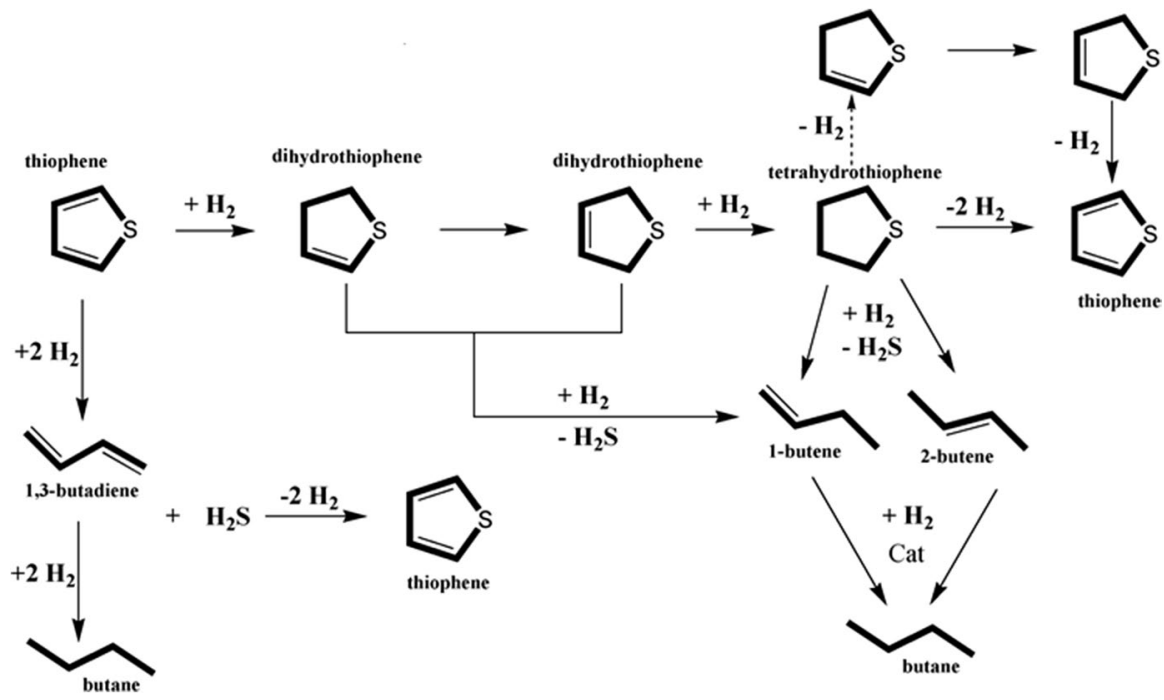

Fig. 9 The scheme of the mechanism of thiophene HDS 
We consider that our present study_applying the radiotracer technique and pulse microanalytical method-can contribute to better understanding of the complicated conversion of $\mathrm{TH}$ on the different sulfided catalysts.

\section{Conclusions}

As our former publication showed [36] the isotope tracer technique is a reliable method for mapping of byproducts of a mechanism. Based on the results of the present study the following statements can be made: the THT is a major intermediate in the conversion of $\mathrm{TH}$ on our single sulfided Mo, NiMo, and Ni catalyst at atmospheric pressure in the pulse microanalytical sytem.

Small amount of 2-HTH and 2,5-DHT could be identified in the hydrogenation process of $\mathrm{TH}$. Both intermediates are more reactive because the stability of these species follows the order: THT $>2,5-\mathrm{DHT}>2-\mathrm{HTH}$. This can provide a good explanation that 2-HTH can hardly observed in the experiment, while THT can be observed easily [37]. The conversion of THT is preferential because both $\mathrm{S}-\mathrm{C}$ bonds are equivalent and have lower energy value than $-\mathrm{CH}_{2}=\mathrm{CH}-\mathrm{SH}$. NiMo has higher activity in this process than Mo and, Ni catalysts.

Funding Open access funding provided by ELKH Wigner Research Centre for Physics.

Open Access This article is licensed under a Creative Commons Attribution 4.0 International License, which permits use, sharing, adaptation, distribution and reproduction in any medium or format, as long as you give appropriate credit to the original author(s) and the source, provide a link to the Creative Commons licence, and indicate if changes were made. The images or other third party material in this article are included in the article's Creative Commons licence, unless indicated otherwise in a credit line to the material. If material is not included in the article's Creative Commons licence and your intended use is not permitted by statutory regulation or exceeds the permitted use, you will need to obtain permission directly from the copyright holder. To view a copy of this licence, visit http://creativecommons.org/licen ses/by/4.0/.

\section{References}

1. Owens PJ, Amberg CH (1961) Thiophene desulfurization by a microreactor technique. Adv Chem 20:182-198

2. Kolbe S (1969) Catalytic hydrodesulfurization of thiophene. VII. Comparison between thiophene, tetrahydrothiophene, and n-butanethiol. Can J Chem 47:352-355

3. Milkowsky RJ, Silvestri AJ, Heinemann H (1974) On the mechanism of thiophene desulfurization. J Catal 34:324-326

4. Houala M, Nag NK, Sapre AV, Broderick DH, Gates BC (1978) Hydrodesulfurization of dibenzothiophene catalyzed by sulfided $\mathrm{CoO}-\mathrm{MoO}_{3} \gamma-\mathrm{Al}_{2} \mathrm{O}_{3}$ : the reaction network. AIChE $\mathrm{J}$ $24: 1015-1021$

5. Hargreaves AE, Ross JRH (1979) An investigation of the mechanism of the hydrodesulfurization of thiophene over sulfided $\mathrm{Co}-\mathrm{MoAl}_{2} \mathrm{O}_{3}$ catalysts: II. The effect of promotion by cobalt on the $\mathrm{C}-\mathrm{S}$ bond cleavage and double-bond hydrogenation/dehydrogenation activities of tetrahydrothiophene and related compounds. J Catal 56:363-376 
6. ZdraŽil M (1982) The chemistry of the hydrodesulphurization process (review). Appl Catal 4:107-123

7. Pokorny P, Zdrazil M (1981) Single and competitive hydrodesulphurization of thiophene and benzo[b]thiophene on molybdenum catalysts. Collect Czech Chem Commun 46:2185-2196

8. Vrinat ML (1983) The kinetics of the hydrodesulfurization process-a review. Appl Catal 6:137-158

9. Schulz H, Do DV (1984) Fast and slow steps of hydrodesulfurization. Bull Soc Chim Belg 93:645-652

10. McCarty KF, Schrader GL (1984) Reduced Molybdenum states in hydrodesulfurization: investigation using chevrel phase catalysts. In: 8th International congress on catalysis

11. McCarty KF, Schrader GL (1987) Deuterodesulfurization of thiophene: an investigation of the reaction mechanism. J Catal 103:261-269

12. Startsev AN (1992) Concerted mechanism of thiophene hydrogenolysis by sulfide HDS catalysts. In: 10th international congress on catalysis, p 585

13. Leglise J, Gestel V, Duchet J-C (1996) Evidence for H2S as active species in the mechanism of thiophene hydrodesulfurization. In: Occelli ML, Chianelli R (eds) Hydrotreating technology for pollution control. Marcel Dekker Inc., New York, pp 147-157

14. Topsoe H, Clausen BS, Massoth FE (1996) Hydrotreating catalysis, science and technology. In: Anderson R, Boudart MM (eds) Catalysis, science and technology, vol 11. Springer, Berlin

15. Schulz H, Schron M, Rahman HM (2000) In: Cerveny L (ed.) Studies in surface science and catalysis. Elsevier, Amsterdam, p 204

16. Borgna A, Hensen EJM, Coulier L, de Croon MHJM, Schouten JC, van Veen JAR, Niemantsverdriet JW (2003) Intrinsic thiophene hydrodesulfurization kinetics of a sulfided $\mathrm{NiMo} / \mathrm{SiO}_{2}$ model catalyst: volcano-type behavior. Catal Lett 90:117-122

17. Moses PG, Hinnemann B, Topsoe H, Norskov JK (2007) The hydrogenation and direct desulfurization reaction pathway in thiophene hydrodesulfurization over $\mathrm{MoS}_{2}$ catalysts at realistic conditions: a density functional study 248:188-203

18. Gudkov BS, Gayday NA, Beranek L (1984) Investigation of the mechanism of thiophene hydrodesulphurization by isotopic method. Collect Czech Chem Commun 49:2400-2409

19. Tétényi P (2006) Use of ${ }^{35} \mathrm{~S}$ radiotracer in catalytic studies. In: Hargreaves JSR, Jackson SD, Webb G (eds) Catalytic science series, vol 4. Imperial College Press, London, pp 31-61

20. Paál Z (2006) Application of ${ }^{14} \mathrm{C}$ radiotracer for the study of heterogeneous catalytic reactions. In: Hargreaves JSR, Jackson SD, Webb G (eds) Catalytic science series, vol 4. Imperial College Press, London, pp 31-61

21. Bussel ME, Somorjai GA (1987) A radiotracer $\left({ }^{14} \mathrm{C}\right)$ and catalytic study of thiophene hydrodesulfurization on the clean and carbided Mo(100) single-crystal surface. J Catal 106:93-104

22. Koltai T, Massoth FE, Tétényi P (2000) A radioisotope flow-circulation tracer method for determination of sulfur uptake and exchange. Reac Kinet Catal Lett 71:85-92

23. Massoth FE, Koltai T, Tétényi P (2001) Theoretical analysis of sulfur exchange experiments. J Catal 203:33-40

24. Kogan VM, Isaguliants GV (2008) The HDS mechanism: which "auxiliary" process takes place-sulfur isotopic exchange or replacement-and why is it important to know it? Catal Today 130:243-248

25. Kogan VM (1998) Transition metal sulfides. Chemistry and catalysis. In: Weber T, Prins R, van Santen R (eds) NATO ASI Series, Kluwer Academic Publishers, 3. High technology, vol. 60, pp $35-271$

26. Varga Z, Szarvas T, Tétényi P et al (2018) The particular characteristics of the active sites of $\mathrm{MoS}_{2}, \mathrm{WS}_{2}$ catalysts in thiophene hydrodesulfurization. Reac Kinet Mech Cat 124:61-74

27. Tétényi P, Schnörch P, Tellinger O (2009) Promoter effect of nickel in thiophene hydrodesulfurization as monitored by sulfur uptake and cyclohexane conversion. Reac Kinet Catal Lett 97:141-150

28. Tétényi P, Ollár T, Szarvas T (2012) Sulfur exchange capacity and thiophene hydrodesulfurization activity of sulfided molybdena-alumina catalysts promoted by nickel. Catal Today 181:148-155

29. Dobrovolszky M, Matusek K, Pál Z, Tétényi P (1993) Conversion of thiophene on molybdenaalumina catalysts containing Group 8-10 metals: effect of H2S uptake. J Chem Soc Farad Trans $89: 3137-3142$ 
30. Koltai T, Galsán V, Tétényi P (1999) Effect of pretreatment of HDS activity of supported NiW and NiMo catalysts. Reac Kinet Catal Lett 67:391-396

31. Tétényi P, Ollár T, Schay Z, Schnörch P, Szarvas T (2008) Sulfur uptake determination on Ni containing molybdena-alumina samples by radioisotope tracer technique. Appl Radiat Isotopes 66:1190-1195

32. Pál Z, Koltai T, Matusek K, Manoli J, Potvin C, Muhler M, Wild U, Tétényi P (2001) Sulfur uptake and exchange, HDS activity and structure of sulfided, $\mathrm{Al}_{2} \mathrm{O}_{3}$ supported $\mathrm{MoO}_{\mathrm{x}}, \mathrm{PdMoO}_{\mathrm{x}}$ and $\mathrm{PtMoO}_{\mathrm{x}}$ catalysts. Phys Chem Chem Phys 3:1535-1543

33. Franklin JL, Dillard JG, Rosenstock HM, Herron JT, Draxl K, Field FH (1969) Ionization P, appearance potentials and heats of formation of gaseous positive ionization potentials NSRDSNBS 26 June Washington. (cited from J.D. Cox, G. Pilcher, thermochemistry of organic and organometallic compounds. London Academic Press, 1970)

34. Allken PW, Sutton LE (1950) Tables of interatomic distances and molecular configurations obtained by electron diffraction in the gas phase. Acta Cryst Cambridge 3:46-72

35. Krikorian OJ, Carpenter JH (1965) J Phys Chem 60:4399 (Cited from J.D. Cox, G. Pilcher: Thermochemistry of Organic and Organometallyc Compounds, London Academic Press 1970)

36. Szarvas T, Eller Z, Kasza T, Ollár T, Tétényi P, Hancsók J (2015) Investigation of radiocarbon $\left({ }^{14} \mathrm{C}\right)$ labeled oleic acid hydrotreating over sulfided alumina supported MoP and NiW catalysts. Appl Catal B 165:245-252

37. Li S, Liu Y, Feng X, Chen X, Yang C (2019) Insights into the reaction pathway of thiophene hydrodesulfurization over corner site of MoS2 catalyst: a density functional theory study. Mol Catal 463:45-53

Publisher's Note Springer Nature remains neutral with regard to jurisdictional claims in published maps and institutional affiliations. 